\title{
A Reevaluation of a Lithic Procurement Site (41BX63) in Converse, Bexar County, Texas
}

Kevin J. Gross

Center for Archaeological Research

Follow this and additional works at: https://scholarworks.sfasu.edu/ita

Part of the American Material Culture Commons, Archaeological Anthropology Commons, Environmental Studies Commons, Other American Studies Commons, Other Arts and Humanities Commons, Other History of Art, Architecture, and Archaeology Commons, and the United States History Commons

Tell us how this article helped you.

This Article is brought to you for free and open access by the Center for Regional Heritage Research at SFA ScholarWorks. It has been accepted for inclusion in Index of Texas Archaeology: Open Access Gray Literature from the Lone Star State by an authorized editor of SFA ScholarWorks. For more information, please contact cdsscholarworks@sfasu.edu. 


\section{A Reevaluation of a Lithic Procurement Site (41BX63) in Converse, Bexar County,}

Texas

\section{Creative Commons License}

\section{(c) (1) \&}

This work is licensed under a Creative Commons Attribution-NonCommercial 4.0 International License 


\title{
A Reevaluation of a Lithic Procurement Site (41BX63) in Converse, Bexar County, Texas
}

\author{
Kevin J. Gross
}

\author{
Robert J. Hard \\ Principal Investigator
}

${ }^{\circledR}$ copyright

Archaeological Survey Report, No. 258

Center for Archaeological Research

The University of Texas at San Antonio

1997 
The following information is provided in accordance with the General Rules of Practice and Procedure, Chapter 41.11 (Investigative Reports), Texas Antiquities Committee:

1. Type of investigation: Testing

2. Project name: Toepperwein Road

3. County: Bexar

4. Principal investigators: Robert J. Hard

5. Name of sponsor: Neflo Realty Trust

6. Texas Antiquities Committee Permit No.: n/a

7. Published by the Center for Archaeological Research, The University of Texas at San Antonio, $6900 \mathrm{~N}$. Loop 1604 W., San Antonio, Texas 78249-0658, 1997

A list of publications offered by the Center for Archaeological Research is available. Call (210) 458-4378; write to the Center for Archaeological Research, The University of Texas at San Antonio, 6900 N. Loop 1604 W., San Antonio, Texas 78249-0658; e-mail to car@lonestar.utsa.edu; or visit CAR's Web site at http://www.csbs.utsa.edu/research/car/index.htm. 


\section{Abstract}

An archaeological survey of 35 acres in Converse, Texas, in northeastern Bexar County, relocated lithic site 41BX63. Extensive shovel testing demonstrated that virtually no subsurface material was present. The surface site was collected and the chipped stone and raw material analyzed. The analysis suggests local chert cobbles were being selected for early and middle stages of tool manufacture at the site. A single diagnostic artifact, a Scallorn point, indicates that site use included the Late Prehistoric period. 


\section{Contents}

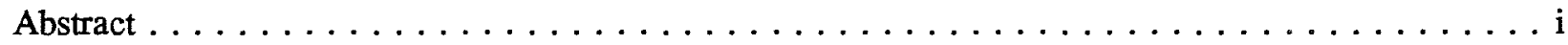

List of Figures $\ldots \ldots \ldots \ldots \ldots \ldots \ldots \ldots \ldots \ldots \ldots \ldots \ldots \ldots \ldots \ldots$ iii

List of Tables $\ldots \ldots \ldots \ldots \ldots \ldots \ldots \ldots \ldots \ldots \ldots \ldots \ldots \ldots \ldots \ldots$ iii

Acknowledgments $\ldots \ldots \ldots \ldots \ldots \ldots \ldots \ldots \ldots \ldots \ldots \ldots \ldots \ldots \ldots \ldots$ iv

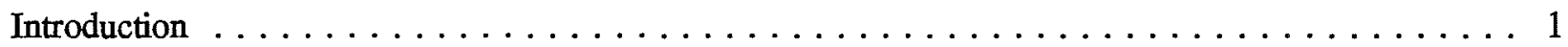

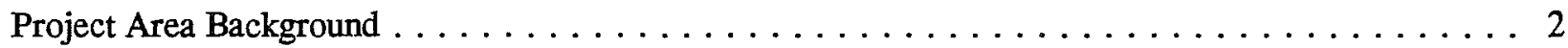

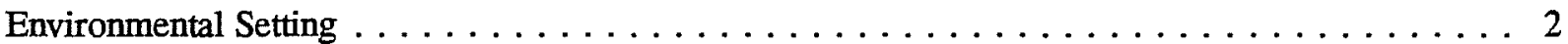

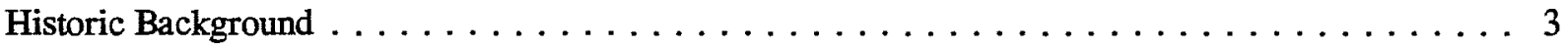

Previous Archaeological Research $\ldots \ldots \ldots \ldots \ldots \ldots \ldots \ldots \ldots \ldots \ldots \ldots \ldots$

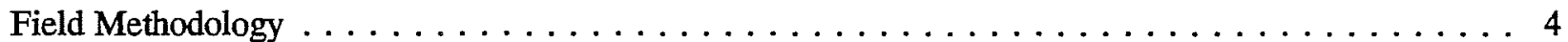

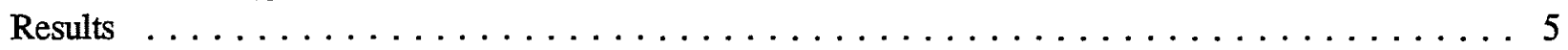

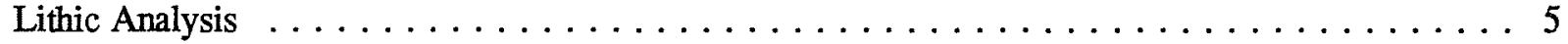

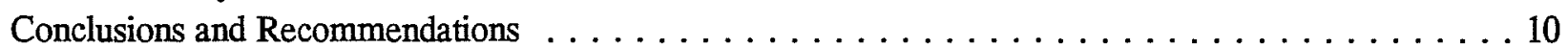

References Cited . . . . . . . . . . . . . . . . . . . . . . . 12

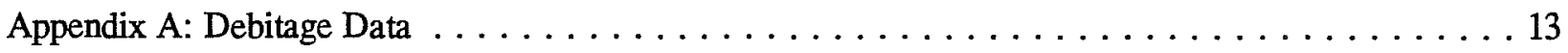

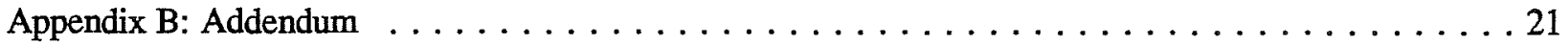




\section{Figures}

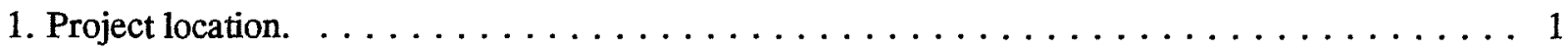

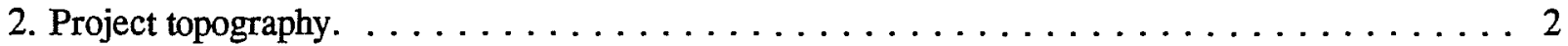

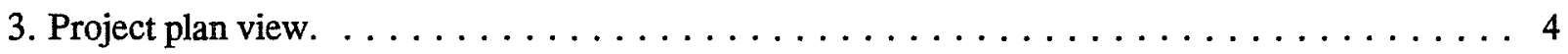

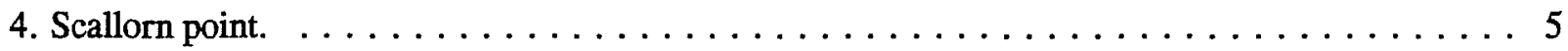

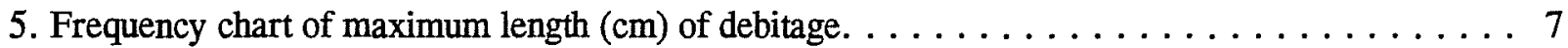

6. Maximum width and thickness of complete bifaces $(\mathrm{n}=23) . \ldots \ldots \ldots \ldots \ldots \ldots$

7. Maximum length and width of bifaces and raw material nodules. $\ldots \ldots \ldots \ldots \ldots \ldots \ldots$

B-1. Biface width and thickness. . . . . . . . . . . . . . . . . . . . 22

\section{Tables}

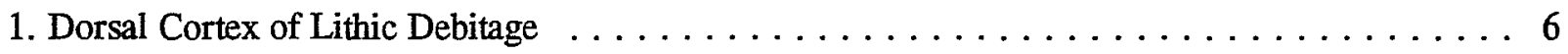

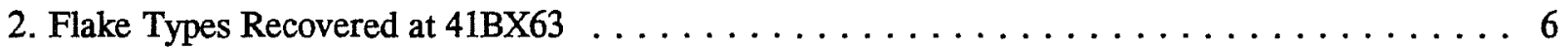

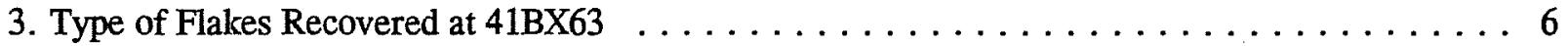

4. Width and Thickness of Complete Bifaces at 41BX63 $\ldots \ldots \ldots \ldots \ldots \ldots \ldots \ldots \ldots$

B-1. Width and Thickness of Complete Bifaces Collected near Hearth Feature. . . . . . . . . . 21 


\section{Acknowledgments}

We would like to acknowledge Neflo Realty Trust, owners of the property, and applaud their concern for protecting Texas's past. We sincerely appreciate the cooperation we received from Charles Reid, of EnviroTech; Lloyd Seiler, of Seiler-Boothe Design Group, Inc.; and Keith Dickerson, of the city of Converse, Department of Public Works. The Southern Texas Archaeological Association presented the owners and the city of Converse with preservation awards for their commitment to this project.

We wish to thank Jimmy Mitchell, a long time resident of the area, for sharing his knowledge of 41BX63. We are grateful to Trevor Phipps for sharing his collection. Thanks are extended to the CAR field crew: John W. Arnn, B. Ward Bramlett, Johanna M. Hunziker, Edgar D. Johnson, Barbara A. Meissner, David L. Nickels, and Kaylee A. Stallings for their hard work, and to Cynthia L. Tennis for her help in the field (and for finishing much of the prefieldwork) and for reviewing the preliminary draft of this report. Bruce K. Moses's work on the maps and illustration and I. Waynne Cox's assistance with the archival research are greatly appreciated. Special thanks are reserved for Dr. Steve A. Tornka for his assistance in the field and patient instruction in the laboratory. Thanks also to Dr. Robert J. Hard, director of CAR, and Dr. C. Britt Bousman, associate director of CAR, co-principal investigators for this project, for their assistance and guidance. Finally, Marcie Renner, the CAR editor, is thanked for preparing this report for final publication. 


\section{Introduction}

In early August 1996, Lloyd Seiler of Seiler• Boothe Design Group, Inc., and Keith Dickerson from the city of Converse, Department of Public Works, contacted the Center for Archaeological Research (CAR) of The University of Texas at San Antonio for advisement about a privately funded construction project that would impact a previously recorded prehistoric site, 41BX63. The site is just west of Toepperwein Road, in northeastern Bexar
County (Figure 1). CAR staff archaeologists visited the 35-acre project area on August 12 and conducted a preliminary reconnaissance and dug two shovel tests. Lithic debris and fire-cracked chert were observed on the surface during this preliminary investigation. Results of the visit were reported to the appropriate individuals and agencies and, due to their concern for the archaeological resources, the property owners, Neflo Realty Trust, decided to contract with CAR to more fully investigate the area before beginning construction.

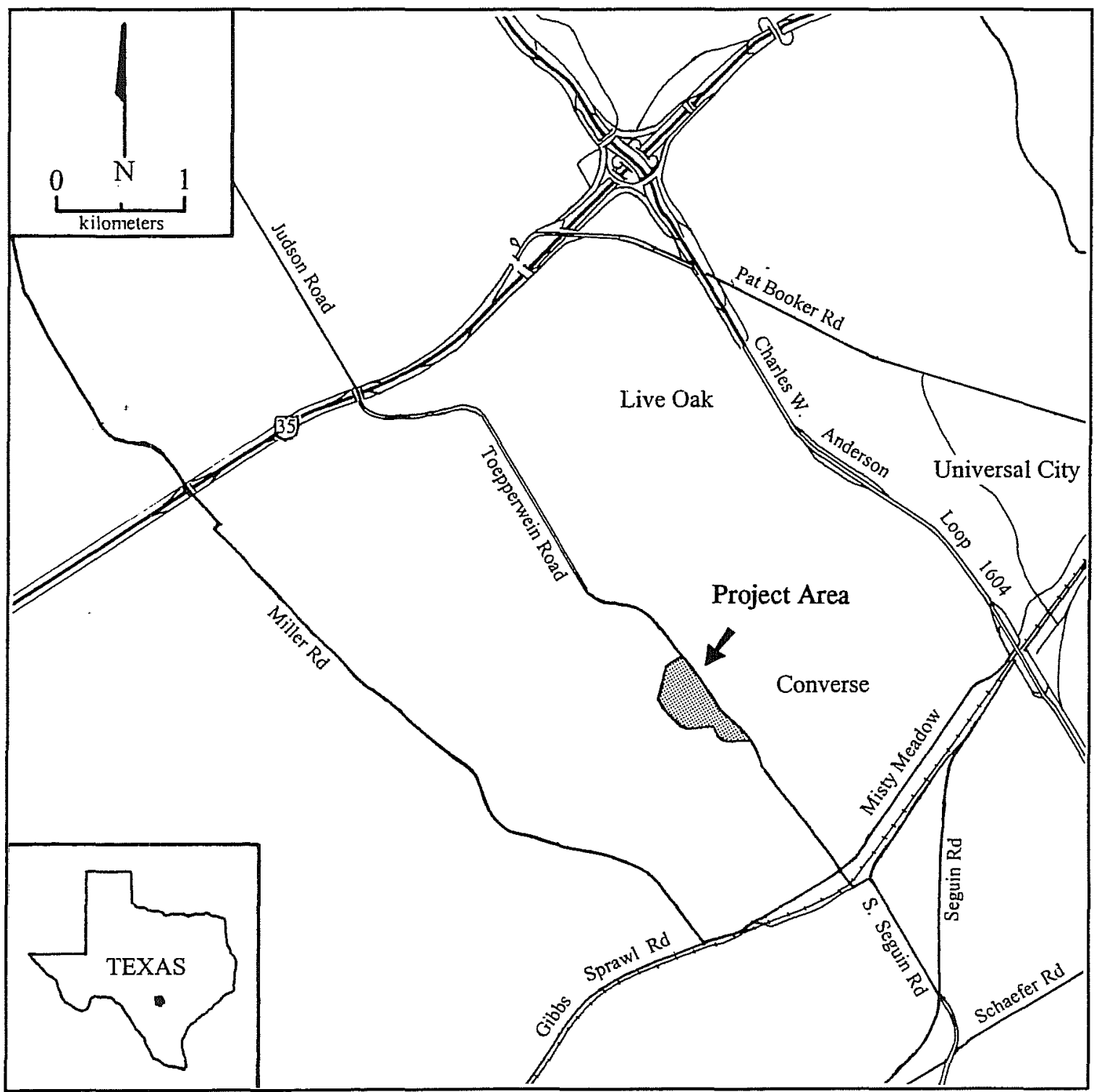

Figure 1. Project location. 
As a result, CAR staff returned later in the month and completed a systematic investigation of the Toepperwein Road project area. A pedestrian survey of the area was completed, 105 shovel tests were excavated, and site 41BX63 was relocated. The site was shovel tested and mapped and a complete surface collection of artifacts was executed. A raw material sample was also collected from the site.

\section{Project Area Background}

\section{Environmental Setting}

The 35-acre project area is located off Toepperwein Road in Converse, Texas, in northeastern Bexar County. The project area is situated between the intermittent Salatrillo and West Salatrillo creeks. Both creeks drain the area northeast to southwest and converge $3.2 \mathrm{~km}$ south of Converse. Major drainages in the area include Cibolo Creek to the north and Martinez and Rosillo creeks to the south.

The project area has two hills on its eastern boundary (Figure 2). The hills slope steeply to the west toward an unnamed, intermittent tributary of the West Salatrillo Creek, and to the east toward Salatrillo Creek. The top of the northernmost hill is $259 \mathrm{~m}$ (849 ft) above mean sea level (amsl), while the more southern hill crests at $251 \mathrm{~m}(824 \mathrm{ft})$ amsl. The unnamed tributary and the Salatrillo flow past the project area at about $229 \mathrm{~m}$ (750 ft) amsl.

Large portions of the project area had been disturbed. Up to five meters of topsoil were removed from an area about 20-30 m wide along the entire northern and northwestern

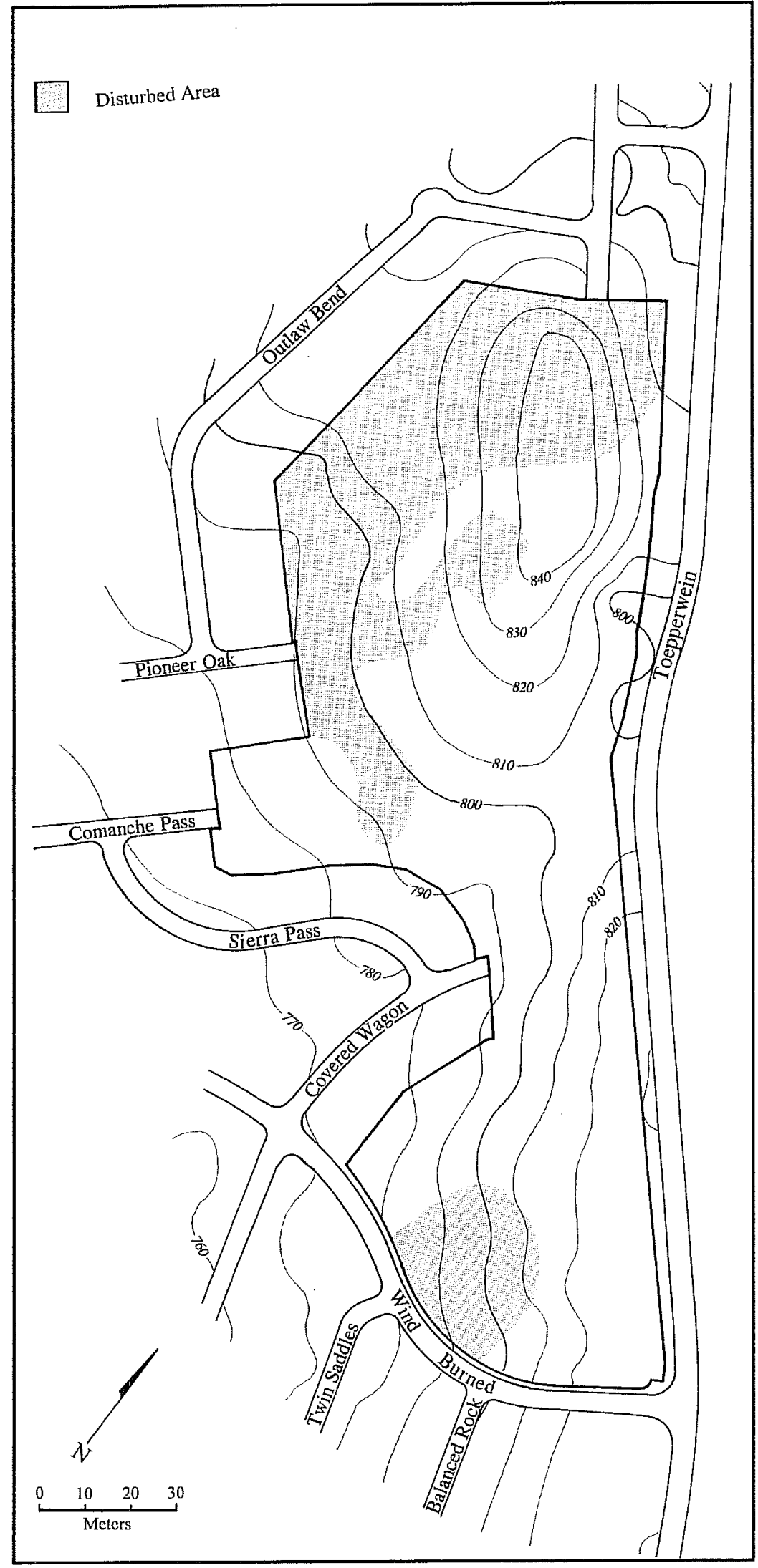

Figure 2. Project topography. 
boundaries for fill material for the construction of a nearby highway. Much of the western boundary has been impacted by construction activities associated with an adjacent housing subdivision. Large areas of the northern hill have been used as a substantial, informal trash dump.

Soils in the project area consist of Houston Series clays. Houston-Sumter clays were identified on the upper slope of the northern hill and on the saddle. Taylor et al. (1991:19) describe the Houston soils in this association as occurring in steeply sloping areas that have been damaged by water erosion. The soil is generally about $20-38 \mathrm{~cm}$ thick on hilltops and about $41-76 \mathrm{~cm}$ thick on the lower part of slopes and saddles. The Sumter soil is a shallow, gravelly clay that occurs as strongly sloping to steep, narrow ridges (Taylor et al. 1991:19). Taylor et al. (1991:20) describe the surface layer of the Sumter soils as grayish brown and about $20 \mathrm{~cm}$ thick. The underlying material is a pale-yellow calcareous marl or clay. The Sumter soils were identified by the underlying marl only in shovel tests excavated on the western-southwestern slopes of the northernmost hill.

Severely eroded Houston clay (HnC3), on 3 to 5 percent slopes, was identified along the southwestern boundary of the project area. The surface layer of the soil is described as being about 25-51 $\mathrm{cm}$ thick. The loss of organic matter makes the soil relatively lighter in color than other Houston soils (Taylor et al. 1991:19).

A Houston black gravelly clay was identified on the southern hill. Taylor et al. (1991:22) suggest that this soil occupies narrow, convex ridges and valley walls in gently rolling landscapes. Typically, the surface layer is black and about $91 \mathrm{~cm}$ thick. It is usually about 10 to 18 percent gravel by volume, but can be as much as 60 percent gravel by volume (Taylor et al. 1991:22).

\section{Historic Background}

Archival records suggest that the project area is a portion of a larger property originally deeded to James Bushell in ca. 1840 by the state of Texas
(W. C. Walsh, 1879, Map of Bexar County, Commission of the General Land Office, copy on file at CAR). In 1877 James Converse purchased the 738acre Bushell survey from Bexar County, which had seized the property for back taxes owed (Bexar County Deed Records [BCDR], Office of the County Clerk, Bexar County Courthouse, San Antonio, Texas, Volume 6:318). Converse was involved in a number of land purchases in the area, acting as a representative of the Galveston, Houston, and San Antonio Railroad Company (BCDR 7:147). The GH\&SA laid track on Converse's property, about $1.25 \mathrm{~km}$ south of the project area. In 1882 Converse sold the property to Edward Hall (BCDR 23:287). There is no evidence to suggest that Converse or Hall ever resided at the property. Eighteen years later, in January 1900 , Hall sold the property to Anton and Ida Schumann (BCDR 167:513). The Schumanns, at an unknown time before 1932, conveyed the portion of the property that contains the current project area to a relative, Albert H. Schumann.

\section{Previous Archaeological Research}

Site 41BX63 was originally recorded in 1971 by an avocational archaeologist, A. Marrou. Marrou described the site as occupying about one acre centered on the crest of the northern hill in the current survey. On the site form, the author reported completing a surface collection of "many tools." A local avocational archaeologist who is familiar with 41BX63 believes that an intact hearth was exposed about $150 \mathrm{~m}$ north of 41BX63 when the area was mined for fill material. The hearth was excavated and recorded by a second avocational archaeologist, but, unfortunately, the hearth was never reported to the Texas Historical Commission. The same informant suggested that the site has been continuously looted for years.

In 1977 CAR archaeologists recorded 41BX435 in Live Oak, Texas (Roemer and Black 1977). The site is about $1.25 \mathrm{~km}$ north of $41 \mathrm{BX} 63$ and the Toepperwein Road project. Along with a moderate amount of lithic debitage, Montell and Ensor dart point were recovered from 41BX435 (Roemer and Black 1977:8). 
Schuetz (1960) recorded two sites-41BX14 and 41BX15-within one kilometer of the current survey area. Site 41BX14, about one kilometer south of the project area on the West Salatrillo Creek, was described as a "work-shop site" containing "crude, heavy, multipurpose tools" and lithic debitage (Schuetz 1960). Site 41BX15, about one kilometer north of the project area, was a large, light lithic scatter. Schuetz (1960) reported finding "tools" and "knives."

CAR surveys along West Salatrillo Creek (Snavely 1986; Wright 1992) identified two additional prehistoric sites. Site 41BX698, about $2.5 \mathrm{~km}$ southeast of the current survey area, was described as a light lithic scatter (Snavely 1986). No tools or temporally diagnostic artifacts were recovered. Site 41BX979, about one kilometer south of the Toepperwein Road project and across the creek from 41BX14, was also described as a light lithic scatter. Wright (1992:4) reports that a chopper and a distal biface, which was probably reused as a hammerstone, were also recovered at $41 \mathrm{BX} 979$.

\section{Field Methodology}

A pedestrian survey of the entire project area was conducted. All undisturbed portions of the project area were shovel tested to detect buried cultural materials (Figure 3). The 105 shovel tests (ST) were excavated at $30-\mathrm{m}$ intervals along the survey transects. All tests were excavated to a maximum depth of 50 $\mathrm{cm}$ in arbitrary 10-cm levels.

Site 41BX63 was relocated and rerecorded. Six additional shovel tests

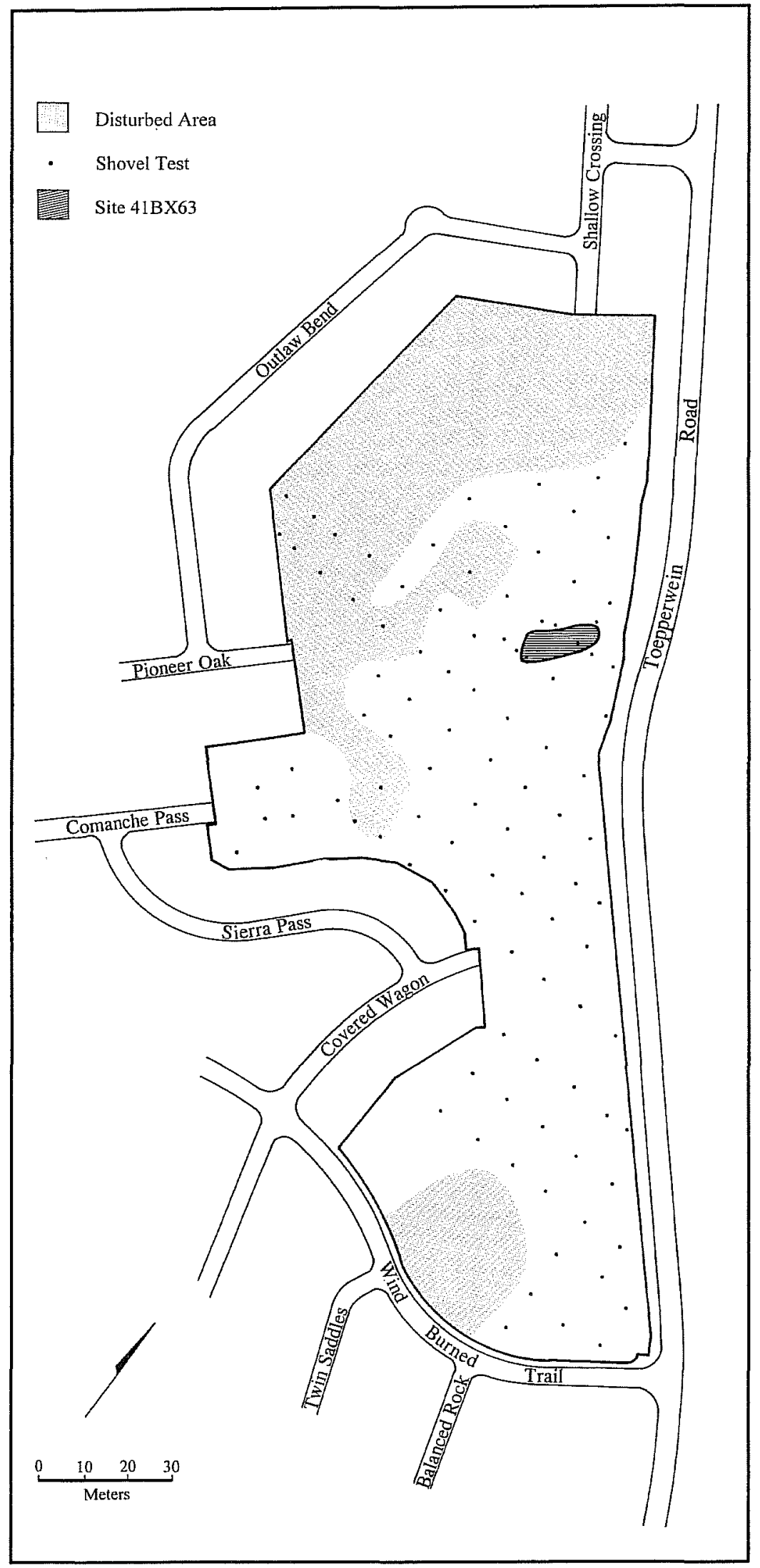

Figure 3. Project plan view. 
(AA1, AA2, AA3, BB1, BB2, and BB3) were excavated around site 41BX63 to better delimit its subsurface extent (Figure 3). Once site boundaries were defined, a surface collection of all cultural material was completed. Also, all raw material with maximum dimensions greater than three centimeters was collected from eight $1-\mathrm{x}-1-\mathrm{m}$ units arbitrarily selected within the site.

\section{Results}

Site $41 \mathrm{BX} 63$ was about $335 \mathrm{sq} . \mathrm{m}$ in area. It is situated along the eastern side of the top of the northern hill in the project area.

In total, 410 lithic artifacts were recovered from 41BX63. The surface assemblage includes 9 cores, 3 choppers, 12 unifaces, 28 bifaces, 358 pieces of lithic debitage, and one diagnostic point. The latter-the only time diagnostic artifact found-

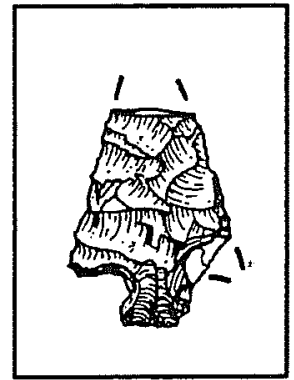

Figure 4. Scallorm point. was the proximal portion of a Scallorn point (Figure 4). Turner and Hester (1993:230) indicate that Scallorns were used throughout south and central Texas in the Late Prehistoric period (ca. A.D. 700-1200). One tertiary flake was recovered from below the surface in ST M2.

Five wooden posts set in concrete, approximately two meters apart and running east-west, were observed about $10 \mathrm{~m}$ south of 41BX63. It is unlikely, however, that the structure represented by these posts was historic. A map from 1932 depicts three structures atop the northern hill near where the posts were located (U.S. Army Corps of Engineers, 1932, Tactical Map, Bracken Quadrangle [2509:3600/49], copy on file at CAR). A resident of the area believes that a house stood near where the posts were located and further suggests that it was destroyed in the late 1960 s. Unfortunately, no features or artifact concentrations were discovered in the area. Instead, large quantities of recently deposited construction debris covered most of the area. It was, therefore, difficult to isolate cultural materials or features associated with the possible structure. A 1904 coin and a sherd of stoneware with an Albany slip interior (which was popular at the turn of the twentieth century) were recovered during surface collection of nearby 41BX63. A recent medallion was found in the southeast corner of the project area.

\section{Lithic Analysis}

Debitage was examined by material type, grain size, flake completeness, platform faceting, maximum dimension, dorsal cortex, and flake type to better understand what activities occurred at the site. Tables 1, 2, and 3 summarize dorsal cortex, faceting, and the type of flakes recovered, respectively. Figure 5 presents the maximum dimension by size category. Figure 5 is slightly flawed, however, as under normal circumstances, reduction of a chert cobble to a finished point would result in a chart that slopes from the upper left corner to the bottom right corner (i.e., there would be significantly more smaller flakes than larger flakes) (Schott 1994). That smaller flakes are under-represented is an artificial result produced by a surface collection rather than excavation and screening. The complete debitage data is presented in Appendix A.

Site 41BX63 was a lithic procurement area, but a careful analysis of the debitage and bifacial artifacts allows us to make tentative conclusions regarding the specific reduction activities associated with chert procurement at this locality. It appears that the site was used for the manufacture of early and middle reduction stage bifacial blanks which were then further reduced into finished tools at a separate location. Single and corticate facets are thought to represent quarrying and early stage reduction activities (Potter et al. 1992:19). At 41BX63, almost 50 percent of the platform-bearing debitage assemblage had either a single facet or cortical facet. Also, the large number of flakes associated with core or platform preparation $(n=160$, almost 45 percent of the debitage assemblage) suggests activities associated with different stages of tool manufacture rather than tool rejuvenation. If the indeterminate flakes are excluded, platform/core 
Table 1. Dorsal Cortex of Lithic Debitage

\begin{tabular}{|c|c|c|}
\hline Flake Type & $\#$ & $\%$ of total \\
\hline Primary & 20 & 5.59 \\
\hline Secondary & 130 & 36.31 \\
\hline Tertiary & 208 & 58.10 \\
\hline Totals & 358 & 100.00 \\
\hline
\end{tabular}

Table 2. Flake Types Recovered at 41BX63

\begin{tabular}{|c|c|c|}
\hline & $\#$ & \% of total \\
\hline Corticate & 36 & 10.06 \\
\hline Single & 135 & 37.71 \\
\hline Double & 28 & 7.82 \\
\hline Three or more & 85 & 23.74 \\
\hline Absent & 74 & 20.67 \\
\hline Totals & 358 & 100.00 \\
\hline
\end{tabular}

Table 3. Type of Flakes Recovered at 41BX63

\begin{tabular}{|c|c|c|}
\hline Flake Type & $\#$ & $\%$ of total \\
\hline Biface manufacture & 101 & 28.21 \\
\hline Biface thinning & 7 & 1.96 \\
\hline Uniface manufacture & 2 & 0.56 \\
\hline Blade & 7 & 1.96 \\
\hline Platform/Core preparation & 160 & 44.69 \\
\hline Indeterminate & 81 & 22.62 \\
\hline Totals & 358 & 100.00 \\
\hline
\end{tabular}




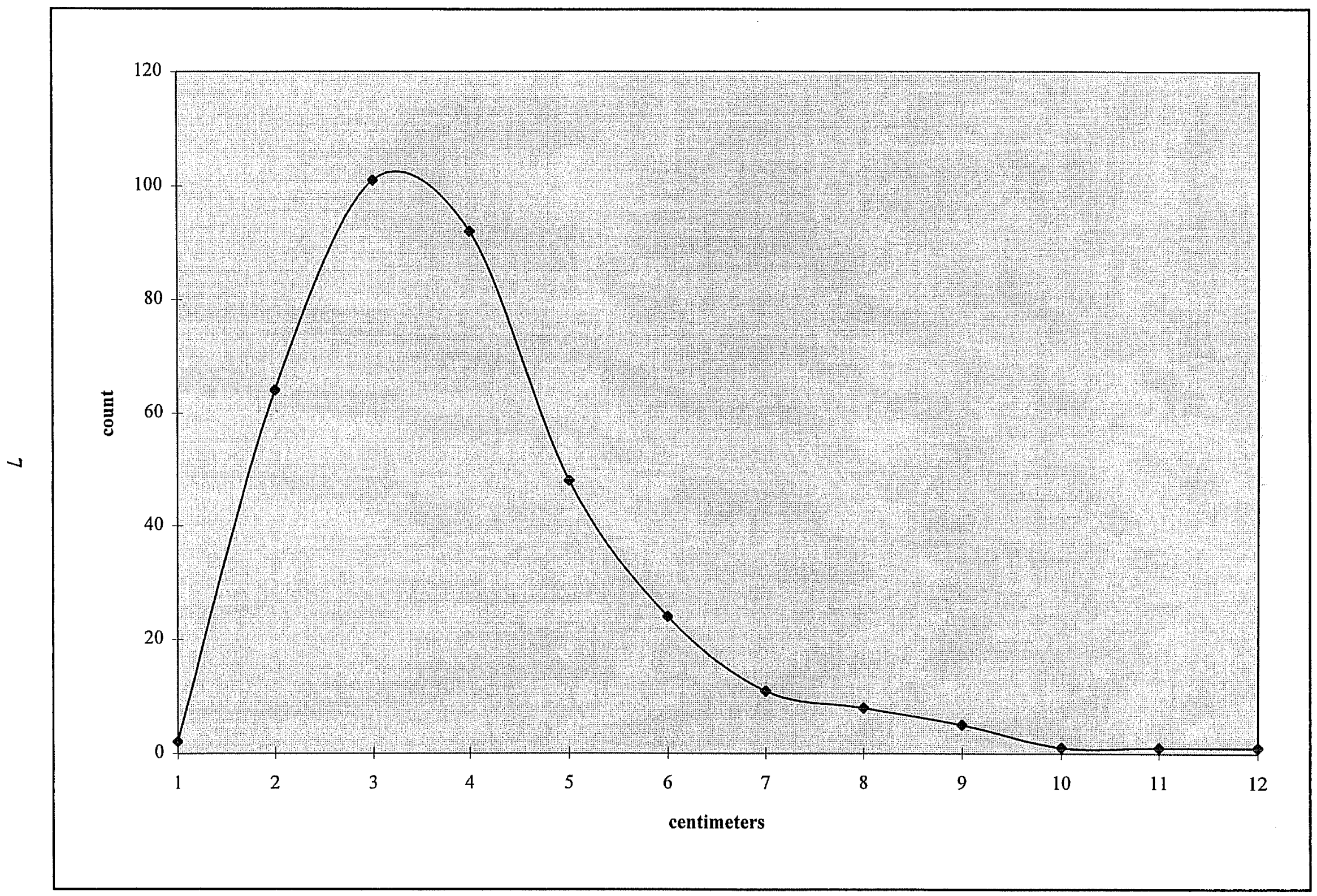

Figure 5. Frequency chart of maximum length $(\mathrm{cm})$ of debitage. 
preparation flakes represent 66 percent of all identifiable flake types.

For this analysis, core or platform preparation flakes, depending on the stage of reduction and the size of the parent material, range in size from less than one centimeter to greater than four centimeters; are either blade, blade-like, or halfmoon in shape; and range from entirely decorticate to entirely corticate. Although all stages of the reduction process are represented, the large number of tertiary flakes $(n=208,58$ percent of the debitage assemblage) suggests that some bifacial reduction of the cobbles did take place at 41BX63 following their initial decortication. Conversely, the scarcity of bifacial thinning flakes $(n=7$, about two percent of the debitage assemblage) indicates that the late reduction phase was not performed at the site and, therefore, the tertiary flakes must represent initial or intermediary bifacial manufacturing activities. Boyd et al. (1996) identify bifacial thinning flakes as "tertiary flakes removed by soft hammerstone or billet, exhibiting a moderate to large number of dorsal flake removal scars, [with] shallow flake scar ridges, and moderate to slight longitudinal curvature."
The bifacial artifact assemblage also suggests that mostly early and middle reduction phases were performed at the site. Most of the bifaces are relatively large and thick. The width and thickness of a biface can be used as a general indicator of the phase of the reduction process (i.e., wider and thicker bifaces typically represent earlier phases of the reduction process) (Callahan 1979). Table 4 summarizes the width and thickness data for the bifaces and includes a width-to-thickness ratio. Figure 6 is a plot of the widths and thicknesses of the complete bifaces $(n=23)$ from 41BX63.

Four distinct clusters are apparent for the bifaces (Figure 6): bifaces with maximum widths less than $3 \mathrm{~cm}$ and thicknesses less than about $1 \mathrm{~cm}(\mathrm{n}=2)$; bifaces with maximum widths between about 3 and $4 \mathrm{~cm}$ and thicknesses between 1 and $4 \mathrm{~cm}(\mathrm{n}=12)$; bifaces with maximum widths between about 5.5 and $8 \mathrm{~cm}$ and thicknesses between 4 and $6 \mathrm{~cm}$ $(n=5)$; and bifaces with widths greater than $8 \mathrm{~cm}$ and thicknesses greater than about $3.5 \mathrm{~cm}(\mathrm{n}=2)$. Callahan (1979:18) suggests that the width-thickness ratio value for biface manufacture increases through the reduction phases. Bifaces from the early and middle reduction phases (preparation and initial

Table 4. Width and Thickness of Complete Bifaces

\begin{tabular}{||c|c|c|}
\hline $\mathbf{W}$ & $\mathbf{T}$ & $\mathbf{W} /$ T Ratio \\
\hline 10.7 & 3.8 & 2.82 \\
\hline 8.7 & 3.6 & 2.42 \\
\hline 6.3 & 5.0 & 1.26 \\
\hline 6.7 & 5.0 & 1.34 \\
\hline 7.4 & 5.2 & 1.42 \\
\hline 5.4 & 2.2 & 2.45 \\
\hline 5.6 & 4.4 & 1.27 \\
\hline 5.0 & 1.8 & 2.78 \\
\hline 3.5 & 1.8 & 1.94 \\
\hline 5.6 & 3.3 & 1.70 \\
\hline 5.3 & 2.6 & 2.04 \\
\hline 3.6 & 1.2 & 3.0 \\
\hline
\end{tabular}

\begin{tabular}{||c|c|c|}
\hline $\mathbf{W}$ & $\mathbf{T}$ & W/T Ratio \\
\hline 4.3 & 1.7 & 2.53 \\
\hline 4.0 & 1.6 & 2.50 \\
\hline 5.3 & 1.6 & 3.31 \\
\hline 6.5 & 4.5 & 1.44 \\
\hline 5.7 & 3.2 & 1.78 \\
\hline 3.6 & 2.8 & 1.29 \\
\hline 5.4 & 2.4 & 2.25 \\
\hline 3.5 & 2.0 & 1.75 \\
\hline 2.8 & 0.8 & 3.50 \\
\hline 4.2 & 1.3 & 3.23 \\
\hline 2.7 & 0.6 & 4.50 \\
\hline
\end{tabular}




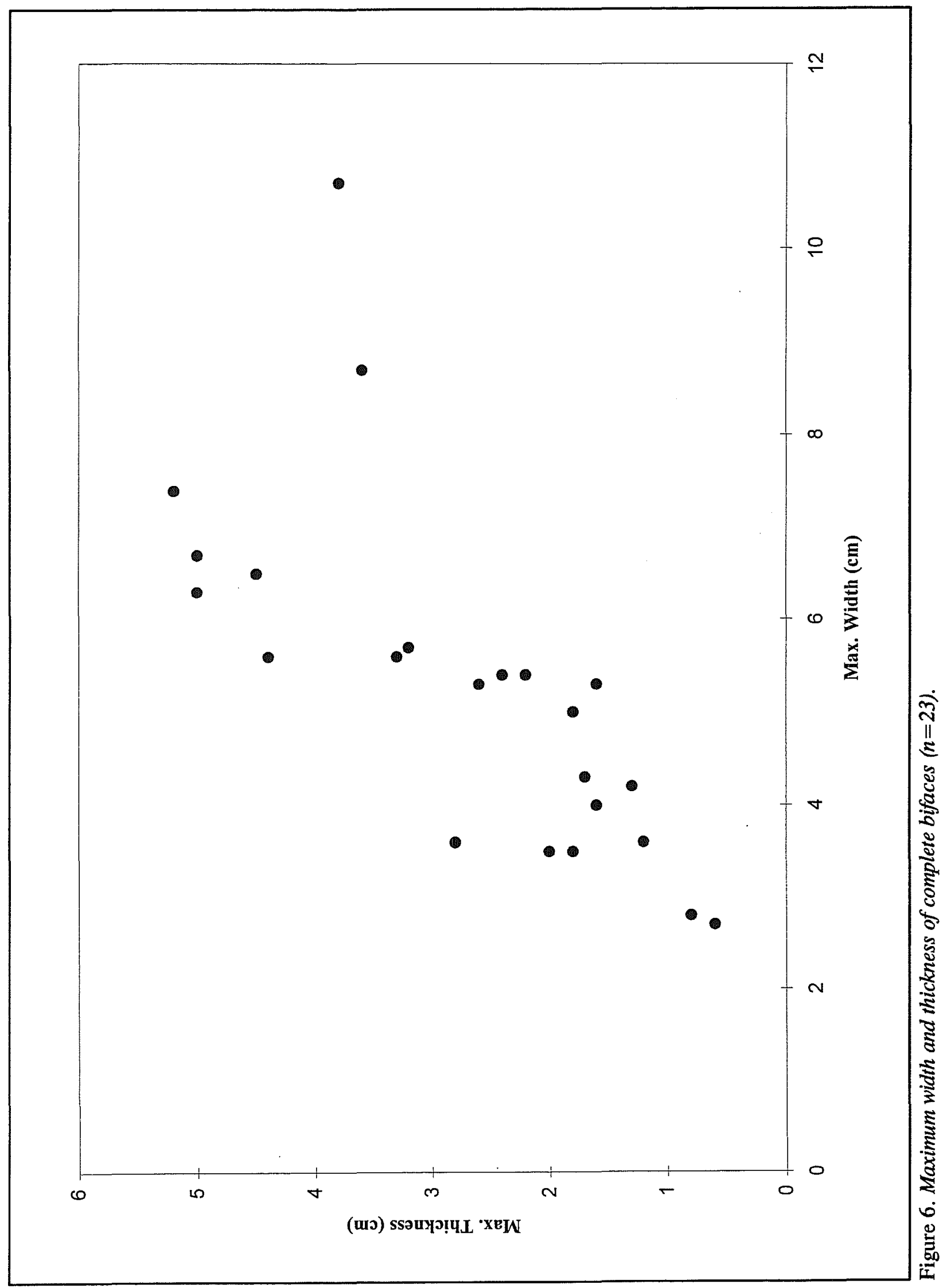


shaping) have width-to-thickness ratios between 2.0 and 4.0. In comparison, a more complete bifacial tool would have a width-to-thickness ratio closer to 10.0 (Callahan 1979:18). As Table 4 suggests, 22 of the 23 bifaces from 41BX63 have width-tothickness ratios of below 4.0. No lithic artifacts were recovered from areas other than 41BX63.

Five hundred fifty-eight raw material samples were collected from the surface of eight 1-x-1-m units. All material larger than three centimeters in maximum diameter was collected. In total, $60.2 \mathrm{~kg}(132.8 \mathrm{lb})$ of unmodified rock was collected. The collection units represent 2.4 percent of 41BX63's total area (335 sq. $\mathrm{m}$ ). If raw materials were evenly distributed across $41 \mathrm{BX} 63$, there may have been as much as $2,500 \mathrm{~kg}$ $(5,500 \mathrm{lb})$ of unselected raw material present. Most of the raw material was small. The mean weight (when measured to the nearest gram) for the collected samples was $107.9 \mathrm{~g}$. The median weight, however, was $57.5 \mathrm{~g}$, suggesting that a few large (heavy) outliers may be pulling up the mean weight. The mean and median maximum lengths (measured to the nearest centimeter) were $5.8 \mathrm{~cm}$ and $5 \mathrm{~cm}$, respectively. Figure 7 plots the maximum length and weight of bifaces and the raw materials. The plot suggests that the materials chosen for the manufacture of bifacial tools were generally larger than a majority of the unmodified raw material.

\section{Conclusions and Recommendations}

A pedestrian survey of the 35-acre Toepperwein Road project area was completed and 105 shovel tests were excavated. A previously recorded prehistoric site (41BX63) was relocated by the CAR staff. A moderate amount of lithic artifacts, including a portion of a time-diagnostic Scallorn point (A.D. 700-1200), was observed and collected from the surface at 41BX63. Only one subsurface artifact was recovered from 41BX63, indicating there is little possibility of buried cultural deposits. No prehistoric artifacts were recovered from any portion of the project area other than at 41BX63.
Archival records suggested that a house may have been constructed in the west-central portion of the property as early as 1900 . We could not, however, identify any features or artifacts from that historic occupation.

The results of the survey suggests that future construction activities should have no effect upon what remains of 41BX63. Therefore, we do not believe that any further archaeological work is necessary. 


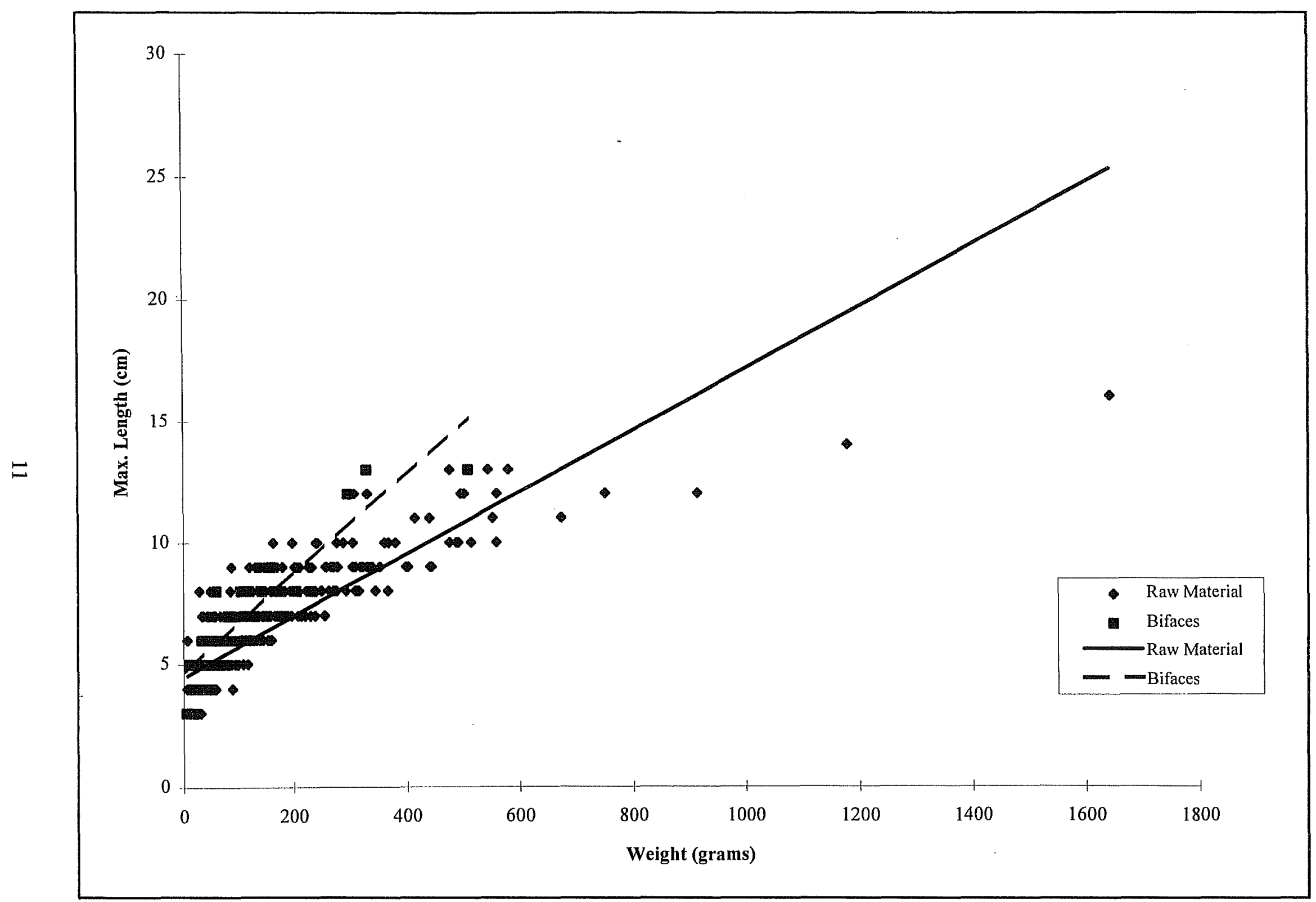

Figure 7. Maximum length and width of bifaces and raw material nodules. 


\section{References Cited}

Black, S. L., and A. J. McGraw

1985 The Panther Springs Creek Site: Cultural Change and Continuity with the Upper Salado Creek Watershed, South-Central, Texas. Archaeological Survey Report, No. 100. Center for Archaeological Research, The University of Texas at San Antonio.

Boyd, D. K., S. A. Tomka, and M. D. Freeman

1996 Caprock Canyonlands Archaeology: A Synthesis of the Late Prehistory and History of Lake Alan Henry and the Texas Panhandle-Plains. Reports of Investigations, Number 110. Prewitt and Associates, Austin. In review.

Callahan, E.

1979 The Basics of Biface Knapping in the Eastern Fluted Point Tradition: A Manual for Flintknappers and Lithic Analysts. Archaeology of Eastern North America 7:1-180

Potter, D. R., C. K. Chandler, and E. Newcomb

1992 Archaeological Salvage Research at 41BX901, A Prehistoric Quarry in Bexar County, Texas. Archaeological Survey Report, No. 211. Center for Archaeological Research, The University of Texas at San Antonio.

Roemer, E., Jr., and S. L. Black

1977 Archaeological Survey and Testing at The City of Live Oak Park, Bexar County, Texas. Archaeological Survey Report, No. 47. Center for Archaeological Research, The University of Texas at San Antonio.

Schott, M. J.

1994 Size and Form in the Analysis of Flake Debris: Review and Recent Approaches. Journal of Archaeological Method and Theory 1:69-110.

Schuetz, M.

1960 Report on the Martinez Creek Survey. Manuscript on file. Center for Archaeological Research, The University of Texas at San Antonio.

Snavely, $\mathbf{R}$.

1986 An Archaeological Survey of Converse City Park, Bexar County, Texas. Archaeological Survey Report, No. 166. Center for Archaeological Research, The University of Texas at San Antonio.

Taylor, F. B., R. B. Hailey, and D. L. Richmond

1991 Soil Survey of Bexar County. Soil Conservation Service. U.S. Department of Agriculture, Washington, D.C.

Turner, S. E. and T. R. Hester

1993 A Field Guide to Stone Artifacts of Texas Indians. Gulf, Houston.

Wright, $\mathrm{K}$.

1992 An Archaeological Survey of Converse City Park Expansion North Branch, Bexar County, Texas. Report on file. Center for Archaeological Research, The University of Texas at San Antonio. 


\section{Appendix A: Debitage Data}

$\begin{array}{ll}\text { Key: } & \text { Raw Material } \\ 1 & \text { chert } \\ 2 & \text { quartzite } \\ 3 & \text { silicified wood } \\ 4 & \text { agate/jasper } \\ 5 & \text { chalcedony } \\ 6 & \text { other }\end{array}$

Grain Size

1 fine, no inclusions

2 fine, with inclusions

3 coarse

Completeness
1 complete
2 proximal
3 medial
4 distal
5 angular chunk

Platform Faceting
$\begin{array}{ll}1 & \text { single } \\ 2 & \text { double } \\ 3 & \text { three plus } \\ 4 & \text { corticate } \\ 5 & \text { absent }\end{array}$

\begin{tabular}{cl}
\multicolumn{3}{c}{ Maximum } \\
1 & $0-10$ \\
2 & $11-20$ \\
3 & $21-30$ \\
4 & $31-40$ \\
5 & $41-50$ \\
6 & $51-60$ \\
7 & $61-70$ \\
8 & $71-80$ \\
9 & $81-90$ \\
10 & $91-100$ \\
11 & $101+$
\end{tabular}

Dorsal Cortex

1 primary

2 secondary

3 tertiary
Flake Type

1 biface manufacture

2 biface thinning

3 biface resharpening

4 uniface manufacture

5 uniface resharpening

6 blade

7 platform/core preparation

8 notching flake

9 sequence

10 channel

11 indeterminate

\begin{tabular}{|c|c|c|c|c|c|c|c|}
\hline Sample & Raw Material & Grain Size & Completeness & Faceting & Max. Dimension & Cortex & Flake Type \\
\hline 1 & 1 & 1 & 2 & 1 & 3 & 3 & 7 \\
\hline 2 & 1 & 2 & 1 & 1 & 4 & 3 & 7 \\
\hline 3 & 1 & 1 & 1 & 3 & 5 & 3 & 1 \\
\hline 4 & 1 & 2 & 1 & 2 & 5 & 2 & 1 \\
\hline 5 & 1 & 1 & 2 & 3 & 5 & 2 & 1 \\
\hline 6 & 1 & 1 & 1 & 1 & 4 & 3 & 7 \\
\hline 7 & 1 & 1 & 1 & 3 & 3 & 3 & 2 \\
\hline 8 & 1 & 2 & 1 & 3 & 5 & 3 & 1 \\
\hline 9 & 1 & 2 & 1 & 3 & 7 & 3 & 7 \\
\hline 10 & 1 & 1 & 1 & 1 & 6 & 3 & 2 \\
\hline 11 & 1 & 2 & 1 & 3 & 6 & 1 & 1 \\
\hline 12 & 1 & 1 & 1 & 3 & 4 & 2 & 7 \\
\hline 13 & 1 & 3 & 1 & 4 & 8 & 2 & 7 \\
\hline 14 & 1 & 1 & 1 & 1 & 6 & 3 & 7 \\
\hline 15 & 1 & 1 & 1 & 1 & 2 & 3 & 7 \\
\hline 16 & 1 & 1 & 1 & 1 & 3 & 3 & 7 \\
\hline 17 & 1 & 1 & 1 & 1 & 7 & 1 & 11 \\
\hline 18 & 1 & 1 & 1 & 1 & 11 & 1 & 7 \\
\hline 19 & 1 & 1 & 2 & 4 & 8 & 2 & 7 \\
\hline 20 & 1 & 2 & 1 & 2 & 5 & 3 & 7 \\
\hline 21 & 1 & 2 & 1 & 1 & 5 & 2 & 1 \\
\hline 22 & 1 & 1 & 2 & 2 & 5 & 2 & 7 \\
\hline 23 & 1 & 1 & 1 & 2 & 6 & 2 & 1 \\
\hline 24 & 1 & 1 & 1 & 4 & 6 & 2 & 7 \\
\hline 25 & 1 & 1 & 1 & 3 & 4 & 3 & 1 \\
\hline
\end{tabular}




\begin{tabular}{|c|c|c|c|c|c|c|c|}
\hline Sample & Raw Material & Grain Size & Completeness & Faceting & Max. Dimension & Cortex & Flake Type \\
\hline 26 & 1 & 1 & 1 & 3 & 4 & 3 & 1 \\
\hline 27 & 1 & 1 & 4 & 5 & 5 & 2 & 1 \\
\hline 28 & 1 & 1 & 1 & 2 & 4 & 2 & 7 \\
\hline 29 & 1 & 1 & 1 & 2 & 4 & 3 & 11 \\
\hline 30 & 1 & 1 & 1 & 3 & 4 & 2 & 1 \\
\hline 31 & 1 & 1 & 1 & 1 & 4 & 3 & 1 \\
\hline 32 & 1 & 3 & 2 & 1 & 4 & 2 & 1 \\
\hline 33 & 1 & 1 & 1 & 1 & 2 & 3 & 7 \\
\hline 34 & 1 & 1 & 1 & 5 & 2 & 3 & 11 \\
\hline 35 & 1 & 1 & 1 & 1 & 3 & 3 & 7 \\
\hline 36 & 1 & 1 & 2 & 1 & 3 & 3 & 7 \\
\hline 37 & 1 & 1 & 1 & 1 & 2 & 3 & 7 \\
\hline 38 & 1 & 1 & 3 & 5 & 2 & 3 & 7 \\
\hline 39 & 1 & 2 & 1 & 4 & 3 & 3 & 7 \\
\hline 40 & 1 & 1 & 2 & 1 & 3 & 2 & 1 \\
\hline 41 & 1 & 1 & 1 & 1 & 3 & 3 & 11 \\
\hline 42 & 1 & 1 & 2 & 3 & 2 & 2 & 7 \\
\hline 43 & 1 & 1 & 1 & 1 & 3 & 1 & 7 \\
\hline 44 & 1 & 1 & 3 & 5 & 2 & 3 & 2 \\
\hline 45 & 1 & 3 & 1 & 1 & 9 & 2 & 7 \\
\hline 46 & 1 & 1 & 1 & 1 & 6 & 2 & 1 \\
\hline 47 & 1 & 1 & 1 & 4 & 6 & 1 & 1 \\
\hline 48 & 1 & 1 & 2 & 4 & 6 & 1 & 1 \\
\hline 49 & 1 & 2 & 2 & 1 & 4 & 2 & 7 \\
\hline 50 & 1 & 1 & 1 & 2 & 7 & 2 & 1 \\
\hline 51 & 1 & 1 & 1 & 2 & 5 & 2 & 7 \\
\hline 52 & 1 & 1 & 1 & 1 & 4 & 3 & 7 \\
\hline 53 & 1 & 1 & 3 & 2 & 4 & 3 & 11 \\
\hline 54 & 1 & 1 & 1 & 3 & 4 & 3 & 7 \\
\hline 55 & 1 & 1 & 1 & 3 & 6 & 3 & 7 \\
\hline 56 & 1 & 1 & 2 & 3 & 4 & 2 & 11 \\
\hline 57 & 1 & 1 & 1 & 1 & 6 & 2 & 7 \\
\hline 58 & 1 & 1 & 1 & 1 & 4 & 2 & 7 \\
\hline 59 & 1 & 1 & 1 & 1 & 5 & 2 & 7 \\
\hline 60 & 1 & 1 & 1 & 3 & 3 & 3 & 7 \\
\hline 61 & 1 & 1 & 3 & 5 & 3 & 3 & 7 \\
\hline 62 & 1 & 1 & 1 & 1 & 5 & 2 & 7 \\
\hline 63 & 1 & 1 & 2 & 1 & 4 & 3 & 7 \\
\hline 64 & 1 & 1 & 1 & 3 & 2 & 3 & 7 \\
\hline 65 & 1 & 2 & 2 & 1 & 3 & 3 & 7 \\
\hline 66 & 1 & 2 & 1 & 1 & 3 & 3 & 7 \\
\hline 67 & 1 & 1 & 1 & 1 & 2 & 3 & 11 \\
\hline 68 & 1 & 1 & 4 & 5 & 3 & 3 & 7 \\
\hline 69 & 1 & 1 & 2 & 3 & 3 & 3 & 7 \\
\hline 70 & 1 & 1 & 1 & 1 & 2 & 3 & 11 \\
\hline 71 & 1 & 1 & 1 & 1 & 5 & 2 & 1 \\
\hline 72 & 1 & 1 & 1 & 1 & 6 & 2 & 7 \\
\hline 73 & 1 & 1 & 1 & 3 & 5 & 3 & 1 \\
\hline 74 & 1 & 1 & 1 & 1 & 6 & 3 & 7 \\
\hline 75 & 1 & 1 & 1 & 1 & 5 & 1 & 1 \\
\hline 76 & 1 & 1 & 1 & 1 & 5 & 3 & 7 \\
\hline 77 & 1 & 1 & 1 & 1 & 2 & 3 & 7 \\
\hline
\end{tabular}




\begin{tabular}{|c|c|c|c|c|c|c|c|}
\hline Sample & Raw Material & Grain Size & Completeness & Faceting & Max. Dimension & Cortex & Flake Type \\
\hline 78 & 1 & 1 & 4 & 5 & 3 & 3 & 7 \\
\hline 79 & 1 & 1 & 1 & 3 & 4 & 2 & 1 \\
\hline 80 & 1 & 1 & 4 & 5 & 4 & 3 & 7 \\
\hline 81 & 1 & 1 & 1 & 1 & 4 & 2 & 7 \\
\hline 82 & 1 & 1 & 1 & 2 & 4 & 3 & 7 \\
\hline 83 & 1 & 1 & 1 & 1 & 2 & 3 & 11 \\
\hline 84 & 1 & 1 & 1 & 3 & 2 & 2 & 7 \\
\hline 85 & 1 & 1 & 1 & 1 & 2 & 3 & 2 \\
\hline 86 & 1 & 1 & 1 & 1 & 4 & 2 & 1 \\
\hline 87 & 1 & 1 & 1 & 3 & 4 & 3 & 1 \\
\hline 88 & 1 & 1 & 4 & 5 & 3 & 3 & 11 \\
\hline 89 & 1 & 1 & 1 & 1 & 3 & 3 & 7 \\
\hline 90 & 1 & 1 & 1 & 1 & 3 & 3 & 1 \\
\hline 91 & 1 & 2 & 1 & 2 & 7 & 2 & 1 \\
\hline 92 & 1 & 1 & 1 & 1 & 4 & 3 & 1 \\
\hline 93 & 1 & 1 & 1 & 1 & 4 & 3 & 6 \\
\hline 94 & 1 & 1 & 1 & 1 & 8 & 2 & 1 \\
\hline 95 & 1 & 1 & 1 & 1 & 6 & 3 & 7 \\
\hline 96 & 1 & 1 & 1 & 3 & 7 & 2 & 7 \\
\hline 97 & 1 & 1 & 4 & 5 & 4 & 2 & 7 \\
\hline 98 & 1 & 1 & 3 & 5 & 3 & 3 & 7 \\
\hline 99 & 1 & 1 & 1 & 1 & 3 & 2 & 11 \\
\hline 100 & 1 & 1 & 1 & 4 & 5 & 2 & 7 \\
\hline 101 & 1 & 1 & 1 & 1 & 3 & 2 & 7 \\
\hline 102 & 1 & 1 & 1 & 3 & 2 & 3 & 7 \\
\hline 103 & 1 & 1 & 1 & 3 & 3 & 3 & 7 \\
\hline 104 & 1 & 2 & 1 & 1 & 3 & 3 & 1 \\
\hline 105 & 1 & 1 & 1 & 4 & 8 & 2 & 1 \\
\hline 106 & 1 & 1 & 1 & 1 & 2 & 3 & 1 \\
\hline 107 & 1 & 1 & 1 & 2 & 3 & 3 & 11 \\
\hline 108 & 1 & 1 & 1 & 1 & 2 & 3 & 7 \\
\hline 109 & 1 & 1 & 1 & 1 & 2 & 3 & 7 \\
\hline 110 & 1 & 1 & 1 & 2 & 4 & 3 & 7 \\
\hline 111 & 1 & 1 & 1 & 1 & 2 & 3 & 11 \\
\hline 112 & 1 & 1 & 1 & 1 & 4 & 3 & 11 \\
\hline 113 & 1 & 1 & 1 & 3 & 4 & 3 & 1 \\
\hline 114 & 1 & 1 & 1 & 3 & 4 & 3 & 7 \\
\hline 115 & 1 & 1 & 1 & 1 & 5 & 2 & 7 \\
\hline 116 & 1 & 1 & 2 & 4 & 6 & 2 & 1 \\
\hline 117 & 1 & 1 & 1 & 3 & 5 & 1 & 1 \\
\hline 118 & 1 & 1 & 2 & 1 & 4 & 3 & 7 \\
\hline 119 & 1 & 1 & 4 & 5 & 3 & 3 & 1 \\
\hline 120 & 1 & 1 & 1 & 1 & 5 & 2 & 7 \\
\hline 121 & 1 & 1 & 1 & 2 & 9 & 2 & 1 \\
\hline 122 & 1 & 1 & 2 & 2 & 4 & 2 & 11 \\
\hline 123 & 1 & 1 & 1 & 4 & 5 & 2 & 1 \\
\hline 124 & 1 & 1 & 4 & 5 & 4 & 2 & 11 \\
\hline 125 & 1 & 1 & 1 & 1 & 4 & 3 & 11 \\
\hline 126 & 1 & 1 & 1 & 1 & 3 & 3 & 1 \\
\hline 127 & 1 & 2 & 1 & 3 & 4 & 3 & 7 \\
\hline 128 & 1 & 1 & 1 & 1 & 2 & 3 & 7 \\
\hline 129 & 1 & 1 & 1 & 2 & 3 & 3 & 7 \\
\hline
\end{tabular}




\begin{tabular}{|c|c|c|c|c|c|c|c|}
\hline Sample & Raw Material & Grain Size & Completeness & Faceling & Max. Dimension & Cortex & Flake Type \\
\hline 130 & 1 & 1 & 1 & 4 & 3 & 1 & 1 \\
\hline 131 & 1 & 1 & 1 & 1 & 2 & 3 & 4 \\
\hline 132 & 1 & 1 & 1 & 1 & 2 & 3 & 7 \\
\hline 133 & 1 & 1 & 1 & 1 & 5 & 3 & 11 \\
\hline 134 & 1 & 1 & 1 & 1 & 5 & 3 & 1 \\
\hline 135 & 1 & 1 & 1 & 3 & 4 & 1 & 1 \\
\hline 136 & 1 & 1 & 2 & 1 & 9 & 2 & 1 \\
\hline 137 & 1 & 3 & 1 & 4 & 9 & 1 & 1 \\
\hline 138 & 1 & 3 & 4 & 5 & 12 & 2 & 11 \\
\hline 139 & 1 & 1 & 2 & 3 & 4 & 3 & 11 \\
\hline 140 & 1 & 2 & 1 & 2 & 8 & 2 & 1 \\
\hline 141 & 1 & 1 & 1 & 1 & 5 & 3 & 1 \\
\hline 142 & 1 & 2 & 2 & 1 & 6 & 1 & 1 \\
\hline 143 & 1 & 1 & 1 & 3 & 6 & 2 & 1 \\
\hline 144 & 1 & 1 & 1 & 1 & 4 & 2 & 7 \\
\hline 145 & 1 & 2 & 1 & 3 & 7 & 2 & 1 \\
\hline 146 & 1 & 2 & 1 & 1 & 6 & 1 & 7 \\
\hline 147 & 1 & 2 & 1 & 4 & 7 & 2 & 7 \\
\hline 148 & 1 & 1 & 1 & 1 & 5 & 3 & 6 \\
\hline 149 & 1 & 1 & 2 & 3 & 5 & 3 & 7 \\
\hline 150 & 1 & 1 & 1 & 1 & 4 & 3 & 11 \\
\hline 151 & 1 & 2 & 1 & 2 & 6 & 2 & 1 \\
\hline 152 & 1 & 1 & 1 & 1 & 4 & 3 & 7 \\
\hline 153 & 1 & 1 & 1 & 1 & 5 & 2 & 6 \\
\hline 154 & 1 & 1 & 1 & 4 & 7 & 2 & 1 \\
\hline 155 & 1 & 1 & 1 & 1 & 3 & 3 & 7 \\
\hline 156 & 1 & 2 & 1 & 4 & 6 & 2 & 1 \\
\hline 157 & 1 & 1 & 2 & 3 & 5 & 3 & 6 \\
\hline 158 & 1 & 1 & 1 & 3 & 4 & 3 & 7 \\
\hline 159 & 1 & 1 & 1 & 1 & 4 & 2 & 7 \\
\hline 160 & 1 & 1 & 4 & 5 & 3 & 3 & 7 \\
\hline 161 & 1 & 1 & 3 & 5 & 4 & 3 & 11 \\
\hline 162 & 1 & 1 & 1 & 2 & 3 & 3 & 11 \\
\hline 163 & 1 & 1 & 1 & 1 & 3 & 2 & 1 \\
\hline 164 & 1 & 1 & 1 & 1 & 4 & 3 & 7 \\
\hline 165 & 1 & 1 & 1 & 1 & 4 & 3 & 1 \\
\hline 166 & 1 & 2 & 1 & 1 & 5 & 2 & 1 \\
\hline 167 & 1 & 2 & 1 & 2 & 5 & 2 & 7 \\
\hline 168 & 1 & 1 & 3 & 5 & 4 & 3 & 1 \\
\hline 169 & 1 & 1 & 1 & 3 & 5 & 2 & 7 \\
\hline 170 & 1 & 2 & 3 & 5 & 5 & 3 & 7 \\
\hline 171 & 1 & 1 & 2 & 3 & 4 & 2 & 7 \\
\hline 172 & 1 & 2 & 1 & 4 & 6 & 1 & 1 \\
\hline 173 & 1 & 2 & 1 & 1 & 6 & 2 & 1 \\
\hline 174 & 1 & 1 & 1 & 1 & 5 & 2 & 11 \\
\hline 175 & 1 & 1 & 2 & 4 & 4 & 2 & 1 \\
\hline 176 & 1 & 1 & 2 & 1 & 3 & 3 & 1 \\
\hline 177 & 1 & 1 & 1 & 1 & 5 & 1 & 1 \\
\hline 178 & 1 & 2 & 1 & 3 & 4 & 3 & 1 \\
\hline 179 & 1 & 2 & 1 & 1 & 5 & 3 & 6 \\
\hline 180 & 1 & 1 & 2 & 1 & 3 & 3 & 11 \\
\hline 181 & 1 & 1 & 1 & 1 & 4 & 2 & 1 \\
\hline
\end{tabular}




\begin{tabular}{|c|c|c|c|c|c|c|c|}
\hline Sample & Raw Material & Grain Size & Completeness & Faceting & Max. Dimension & Cortex & Flake Type \\
\hline 182 & 1 & 1 & 1 & 1. & 2 & 2 & 7 \\
\hline 183 & 1 & 1 & 3 & 5 & 4 & 3 & 11 \\
\hline 184 & 1 & 1 & 5 & 5 & 5 & 2 & 11 \\
\hline 185 & 1 & 1 & 1 & 1 & 5 & 3 & 1 \\
\hline 186 & 1 & 3 & 1 & 4 & 5 & 2 & 1 \\
\hline 187 & 1 & 2 & 1 & 3 & 5 & 2 & 1 \\
\hline 188 & 1 & 1 & 1 & 1 & 5 & 2 & 1 \\
\hline 189 & 1 & 2 & 1 & 3 & 3 & 3 & 7 \\
\hline 190 & 1 & 1 & 1 & 1 & 2 & 3 & 7 \\
\hline 191 & 1 & 1 & 1 & 4 & 4 & 2 & 11 \\
\hline 192 & 1 & 1 & 2 & 2 & 4 & 2 & 11 \\
\hline 193 & 1 & 1 & 1 & 3 & 6 & 3 & 1 \\
\hline 194 & 1 & 1 & 3 & 5 & 3 & 3 & 1 \\
\hline 195 & 1 & 1 & 3 & 5 & 4 & 2 & 11 \\
\hline 196 & 1 & 2 & 1 & 1 & 7 & 3 & 7 \\
\hline 197 & 1 & 1 & 1 & 4 & 4 & 1 & 1 \\
\hline 198 & 1 & 1 & 1 & 3 & 4 & 3 & 11 \\
\hline 199 & 1 & 2 & 1 & 3 & 4 & 2 & 7 \\
\hline 200 & 1 & 2 & 1 & 3 & 3 & 3 & 7 \\
\hline 201 & 1 & 1 & 2 & 2 & 4 & 3 & 7 \\
\hline 202 & 1 & 1 & 4 & 5 & 5 & 1 & 7 \\
\hline 203 & 1 & 2 & 1 & 2 & 4 & 3 & 1 \\
\hline 204 & 1 & 1 & 1 & 3 & 3 & 2 & 7 \\
\hline 205 & 1 & 1 & 1 & 1 & 3 & 3 & 7 \\
\hline 206 & 1 & 1 & 1 & 2 & 3 & 2 & 7 \\
\hline 207 & 1 & 1 & 1 & 1 & 3 & 3 & 7 \\
\hline 208 & 1 & 1 & 2 & 1 & 3 & 3 & 11 \\
\hline 209 & 1 & 1 & 1 & 1 & 3 & 3 & 11 \\
\hline 210 & 1 & 1 & 3 & 5 & 3 & 3 & 11 \\
\hline 211 & 1 & 1 & 1 & 3 & 4 & 1 & 7 \\
\hline 212 & 1 & 1 & 1 & 1 & 5 & 2 & 7 \\
\hline 213 & 1 & 1 & 1 & 4 & 3 & 2 & 7 \\
\hline 214 & 1 & 1 & 2 & 1 & 3 & 2 & 7 \\
\hline 215 & 1 & 1 & 4 & 5 & 3 & 3 & 7 \\
\hline 216 & 1 & 1 & 1 & 1 & 3 & 2 & 11 \\
\hline 217 & 1 & 1 & 3 & 5 & 3 & 3 & 1 \\
\hline 218 & 1 & 2 & 3 & 5 & 8 & 2 & 1 \\
\hline 219 & 1 & 1 & 2 & 4 & 4 & 2 & 1 \\
\hline 220 & 1 & 1 & 1 & 3 & 4 & 2 & 1 \\
\hline 221 & 1 & 1 & 2 & 3 & 3 & 3 & 7 \\
\hline 222 & 1 & 1 & 2 & 3 & 3 & 3 & 7 \\
\hline 223 & 1 & 2 & 2 & 1 & 5 & 2 & 1 \\
\hline 224 & 1 & 1 & 1 & 3 & 3 & 3 & 7 \\
\hline 225 & 1 & 1 & 2 & 1 & 3 & 3 & 7 \\
\hline 226 & 1 & 1 & 1 & 1 & 4 & 3 & 6 \\
\hline 227 & 1 & 1 & 1 & 4 & 4 & 2 & 7 \\
\hline 228 & 1 & 1 & 1 & 1 & 3 & 3 & 1 \\
\hline 229 & 1 & 1 & 2 & 3 & 4 & 2 & 7 \\
\hline 230 & 1 & 1 & 1 & 1 & 5 & 2 & 7 \\
\hline 231 & 1 & 1 & 1 & 3 & 4 & 3 & 11 \\
\hline 232 & 1 & 1 & 1 & 2 & 4 & 2 & 1 \\
\hline 233 & 1 & 1 & 4 & 5 & 4 & $\begin{array}{r}3 \\
\end{array}$ & 1 \\
\hline
\end{tabular}




\begin{tabular}{|c|c|c|c|c|c|c|c|}
\hline Sample & Raw Material & Grain Size & Completeness & Faceting & Max. Dimension & Cortex & Flake Type \\
\hline 234 & 1 & 1 & 2 & 3 & 4 & 3 & 7 \\
\hline 235 & 1 & 1 & 1 & 1 & 3 & 2 & 1 \\
\hline 236 & 1 & 1 & 1 & 3 & 2 & 2 & 7 \\
\hline 237 & 1 & 1 & 1 & 3 & 3 & 3 & 7 \\
\hline 238 & 1 & 1 & 1 & 1 & 3 & 2 & 1 \\
\hline 239 & 1 & 1 & 2 & 1 & 4 & 2 & 7 \\
\hline 240 & 1 & 1 & 3 & 5 & 4 & 2 & 1 \\
\hline 241 & 1 & 1 & 1 & 1 & 3 & 3 & 11 \\
\hline 242 & 1 & 1 & 4 & 5 & 3 & 3 & 11 \\
\hline 243 & 1 & 2 & 1 & 3 & 10 & 2 & 11 \\
\hline 244 & 1 & 2 & 1 & 4 & 6 & 2 & 1 \\
\hline 245 & 1 & 1 & 3 & 5 & 4 & 3 & 1 \\
\hline 246 & 1 & 1 & 1 & 1 & 3 & 2 & 1 \\
\hline 247 & 1 & 1 & 2 & 4 & 4 & 3 & 11 \\
\hline 248 & 1 & 1 & 1 & 4 & 3 & 3 & 7 \\
\hline 249 & 1 & 1 & 1 & 3 & 2 & 3 & 11 \\
\hline 250 & 1 & 1 & 3 & 5 & 4 & 3 & 11 \\
\hline 251 & 1 & 3 & 1 & 1 & 3 & 3 & 1 \\
\hline 252 & 1 & 1 & 1 & 1 & 3 & 3 & 1 \\
\hline 253 & 1 & 1 & 1 & 3 & 3 & 3 & 7 \\
\hline 254 & 1 & 1 & 1 & 3 & 4 & 2 & 7 \\
\hline 255 & 1 & 1 & 3 & 5 & 3 & 3 & 11 \\
\hline 256 & 1 & 2 & 1 & 1 & 4 & 3 & 7 \\
\hline 257 & 1 & 1 & 2 & 3 & 3 & 3 & 11 \\
\hline 258 & 1 & 1 & 1 & 1 & 2 & 3 & 11 \\
\hline 259 & 1 & 1 & 3 & 5 & 3 & 3 & 7 \\
\hline 260 & 1 & 1 & 1 & 1 & 4 & 2 & 7 \\
\hline 261 & 1 & 1 & 2 & 3 & 4 & 2 & 7 \\
\hline 262 & 1 & 1 & 4 & 5 & 3 & 3 & 1 \\
\hline 263 & 1 & 1 & 2 & 1 & 3 & 2 & 4 \\
\hline 264 & 1 & 2 & 4 & 5 & 3 & 3 & 1 \\
\hline 265 & 1 & 1 & 3 & 5 & 4 & 3 & 7 \\
\hline 266 & 1 & 1 & 3 & 5 & 3 & 3 & 7 \\
\hline 267 & 1 & 1 & 1 & 4 & 4 & 2 & 7 \\
\hline 268 & 1 & 1 & 2 & 3 & 4 & 3 & 1 \\
\hline 269 & 1 & 1 & 3 & 5 & 3 & 2 & 11 \\
\hline 270 & 1 & 1 & 4 & 5 & 3 & 3 & 11 \\
\hline 271 & 1 & 1 & 3 & 5 & 3 & 3 & 11 \\
\hline 272 & 1 & 1 & 2 & 3 & 3 & 3 & 7 \\
\hline 273 & 1 & 1 & 1 & 3 & 3 & 1 & 7 \\
\hline 274 & 1 & 1 & 2 & 3 & 3 & 2 & 7 \\
\hline 275 & 1 & 1 & 1 & 4 & 2 & 3 & 11 \\
\hline 276 & 1 & 1 & 4 & 5 & 2 & 2 & 11 \\
\hline 277 & 1 & 1 & 2 & 3 & 3 & 3 & 7 \\
\hline 278 & 1 & 1 & 4 & 5 & 4 & 2 & 11 \\
\hline 279 & 1 & 1 & 4 & 5 & 2 & 3 & 7 \\
\hline 280 & 1 & 1 & 1 & 3 & 2 & 3 & 7 \\
\hline 281 & 1 & 1 & 2 & 2 & 3 & 3 & 7 \\
\hline 282 & 1 & 1 & 2 & 3 & 4 & 2 & 1 \\
\hline 283 & 1 & 1 & 1 & 2 & 2 & 3 & 7 \\
\hline 284 & 1 & 1 & 1 & 1 & 3 & 2 & 11 \\
\hline 285 & 1 & 1 & 1 & 3 & 3 & 3 & 7 \\
\hline
\end{tabular}




\begin{tabular}{|c|c|c|c|c|c|c|c|}
\hline Sample & Raw Material & Grain Size & Completeness & Faceting & Max. Dimension & Cortex & Flake Type \\
\hline 286 & 1 & 1 & 1 & 3 & 4 & 3 & 11 \\
\hline 287 & 1 & 2 & 1 & 1 & 1 & 3 & 11 \\
\hline 288 & 1 & 1 & 1 & 1 & 2 & 3 & 11 \\
\hline 289 & 1 & 1 & 1 & 3 & 3 & 3 & 7 \\
\hline 290 & 1 & 1 & 1 & 1 & 2 & 3 & 7 \\
\hline 291 & 1 & 1 & 1 & 1 & 2 & 3 & 7 \\
\hline 292 & 1 & 1 & 1 & 1 & 2 & 3 & 11 \\
\hline 293 & 1 & 1 & 1 & 1 & 2 & 3 & 7 \\
\hline 294 & 1 & 1 & 1 & 3 & 3 & 2 & 7 \\
\hline 295 & 1 & 1 & 1 & 1 & 2 & 3 & 11 \\
\hline 296 & 1 & 1 & 4 & 5 & 2 & 3 & 11 \\
\hline 297 & 1 & 1 & 1 & 1 & 3 & 2 & 11 \\
\hline 298 & 1 & 1 & 1 & 3 & 3 & 2 & 7 \\
\hline 299 & 1 & 1 & 1 & 4 & 2 & 2 & 11 \\
\hline 300 & 1 & 1 & 1 & 1 & 2 & 3 & 11 \\
\hline 301 & 1 & 1 & 2 & 1 & 2 & 3 & 7 \\
\hline 302 & 1 & 1 & 1 & 1 & 2 & 3 & 7 \\
\hline 303 & 1 & 1 & 1 & 1 & 2 & 3 & 11 \\
\hline 304 & 1 & 1 & 1 & 4 & 3 & 1 & 7 \\
\hline 305 & 1 & 1 & 2 & 3 & 4 & 2 & 7 \\
\hline 306 & 1 & 1 & 3 & 5 & 2 & 3 & 11 \\
\hline 307 & 1 & 1 & 1 & 3 & 3 & 3 & 7 \\
\hline 308 & 1 & 1 & 1 & 3 & 2 & 2 & 11 \\
\hline 309 & 1 & 1 & 3 & 5 & 2 & 3 & 11 \\
\hline 310 & 1 & 1 & 1 & 3 & 2 & 3 & 7 \\
\hline 311 & 1 & 1 & 4 & 5 & 4 & 2 & 1 \\
\hline 312 & 1 & 1 & 2 & 3 & 2 & 3 & 7 \\
\hline 313 & 1 & 1 & 1 & 4 & 2 & 3 & 7 \\
\hline 314 & 1 & 1 & 1 & 4 & 3 & 3 & 7 \\
\hline 315 & 1 & 1 & 4 & 5 & 2 & 3 & 7 \\
\hline 316 & 1 & 1 & 1 & 4 & 2 & 3 & 7 \\
\hline 317 & 1 & 1 & 4 & 5 & 3 & 2 & 7 \\
\hline 318 & 1 & 1 & 5 & 5 & 2 & 3 & 11 \\
\hline 319 & 1 & 1 & 3 & 5 & 3 & 3 & 2 \\
\hline 320 & 1 & 1 & 3 & 5 & 3 & 3 & 2 \\
\hline 321 & 1 & 1 & 4 & 5 & 2 & 3 & 7 \\
\hline 322 & 1 & 1 & 3 & 5 & 2 & 3 & 7 \\
\hline 323 & 1 & 1 & 4 & 5 & 2 & 2 & 11 \\
\hline 324 & 1 & 1 & 3 & 5 & 2 & 2 & 7 \\
\hline 325 & 1 & 1 & 4 & 5 & 3 & 3 & 7 \\
\hline 326 & 1 & 1 & 2 & 1 & 2 & 3 & 7 \\
\hline 327 & 1 & 2 & 3 & 5 & 4 & 3 & 11 \\
\hline 328 & 1 & 1 & 5 & 5 & 2 & 3 & 11 \\
\hline 329 & 1 & 1 & 5 & 5 & 3 & 3 & 11 \\
\hline 330 & 1 & 1 & 4 & 5 & 4 & 3 & 11 \\
\hline 331 & 1 & 1 & 3 & 5 & 2 & 3 & 7 \\
\hline 332 & 1 & 1 & 2 & 1 & 3 & 3 & 7 \\
\hline 333 & 1 & 1 & 3 & 5 & 2 & 3 & 11 \\
\hline 334 & 1 & 1 & 3 & 5 & 2 & 3 & 11 \\
\hline 335 & 1 & 1 & 3 & 5 & 1 & 3 & 11 \\
\hline 336 & 1 & 1 & 3 & 5 & 2 & 2 & 7 \\
\hline 337 & 1 & 2 & 3 & 5 & 4 & 3 & 1 \\
\hline
\end{tabular}




\begin{tabular}{|c|c|c|c|c|c|c|c|}
\hline Sample & Raw Material & Grain Size & Completeness & Faceting & Max. Dimension & Cortex & Flake Type \\
\hline 338 & 1 & 1 & 1 & 2 & 2 & 3 & 7 \\
\hline 339 & 1 & 2 & 5 & 5 & 5 & 3 & 11 \\
\hline 340 & 1 & 1 & 1 & 1 & 7 & 2 & 1 \\
\hline 341 & 1 & 2 & 1 & 3 & 6 & 2 & 1 \\
\hline 342 & 1 & 2 & 1 & 1 & 7 & 2 & 1 \\
\hline 343 & 1 & 2 & 1 & 4 & 9 & 2 & 1 \\
\hline 344 & 1 & 1 & 1 & 3 & 8 & 2 & 1 \\
\hline 345 & 1 & 1 & 1 & 3 & 5 & 3 & 1 \\
\hline 346 & 1 & 1 & 3 & 5 & 8 & 2 & 1 \\
\hline 347 & 1 & 1 & 1 & 3 & 5 & 2 & 6 \\
\hline 348 & 1 & 1 & 1 & 4 & 5 & 2 & 1 \\
\hline 349 & 1 & 1 & 1 & 3 & 4 & 3 & 11 \\
\hline 350 & 1 & 1 & 1 & 1 & 4 & 3 & 7 \\
\hline 351 & 1 & 1 & 2 & 3 & 5 & 3 & 11 \\
\hline 352 & 1 & 1 & 1 & 4 & 4 & 2 & 11 \\
\hline 353 & 1 & 1 & 1 & 3 & 3 & 3 & 1 \\
\hline 354 & 1 & 1 & 3 & 5 & 3 & 3 & 11 \\
\hline 355 & 1 & 1 & 3 & 5 & 3 & 3 & 11 \\
\hline 356 & 1 & 1 & 2 & 1 & 3 & 3 & 7 \\
\hline 357 & 1 & 1 & 3 & 5 & 3 & 3 & 11 \\
\hline 358 & 1 & 1 & 3 & 5 & 3 & 3 & 2 \\
\hline
\end{tabular}




\section{Appendix B: Addendum}

Artifacts collected as a part of the previously described avocational activities on the property were brought to CAR after the current project had been completed. Most of these were collected in the vicinity of the now-destroyed hearth feature believed to have been located about $150 \mathrm{~m}$ north of 41BX63. These artifacts include two probable "Butted Knife" bifaces; one Guadalupe biface; 10 non-diagnostic bifaces; two incomplete, nondiagnostic bifaces; a uniface; a chopper; two edgemodified tertiary flakes; and a tertiary flake. A hand forged trowel, collected from near the historic structure, was also examined. Unfortunately, field maps and drawings do not exist for the hearth or the artifacts.

The Butted Knife and Guadalupe bifaces suggest multiple occupations of the Toepperwein Road project area. More importantly, these tools indicate that a fuller range of activities, in addition to lithic procurement, may have been performed at 41BX63. Turner and Hester (1993:243) believe that Butted Knife bifaces were used in the late Archaic period (650-300 B.C.) for butchering meat or cutting soft plants. Guadalupe bifaces are believed to have been hafted or unhafted woodworking tools used for a relatively brief period of time in the Early Archaic (ca. 3500 B.C.), primarily along drainage systems flowing towards the Gulf Coast from the Edwards Plateau (Black and McGraw 1985:142-151; Turner and Hester 1993:256-260).

Table B-1 presents the width, thickness, and widthto-thickness ratios for the 10 unprovenienced, complete bifaces. Figure B-1 incorporates the width and thickness measurements of these additional bifaces (represented by the square markers) with the 23 previously described bifaces from 41BX63 (represented by the circular markers).

The new bifaces data support earlier conclusions that 41BX63 was used as an early to middle phase lithic reduction site. In addition, the presence of temporally diagnostic, specialized tools (the Butted Knife and Guadalupe bifaces), indicates that 41BX63 was used over time for multiple activities.

Table B-1. Width and Thickness of Complete Bifaces Collected near Hearth Feature

\begin{tabular}{|c|c|c|}
\hline Max. Width (cm) & Max. Thickness (cm) & W/T Ratio \\
\hline 4.9 & 2.0 & 2.45 \\
\hline 4.1 & 1.2 & 3.42 \\
\hline 3.9 & 2.4 & 1.63 \\
\hline 5.8 & 3.1 & 1.87 \\
\hline 7.5 & 3.2 & 2.34 \\
\hline 6.1 & 3.1 & 1.97 \\
\hline 5.6 & 2.2 & 2.55 \\
\hline 5.6 & 3.2 & 1.75 \\
\hline 3.2 & 0.9 & 3.56 \\
\hline 3.9 & 1.2 & 3.25 \\
\hline
\end{tabular}




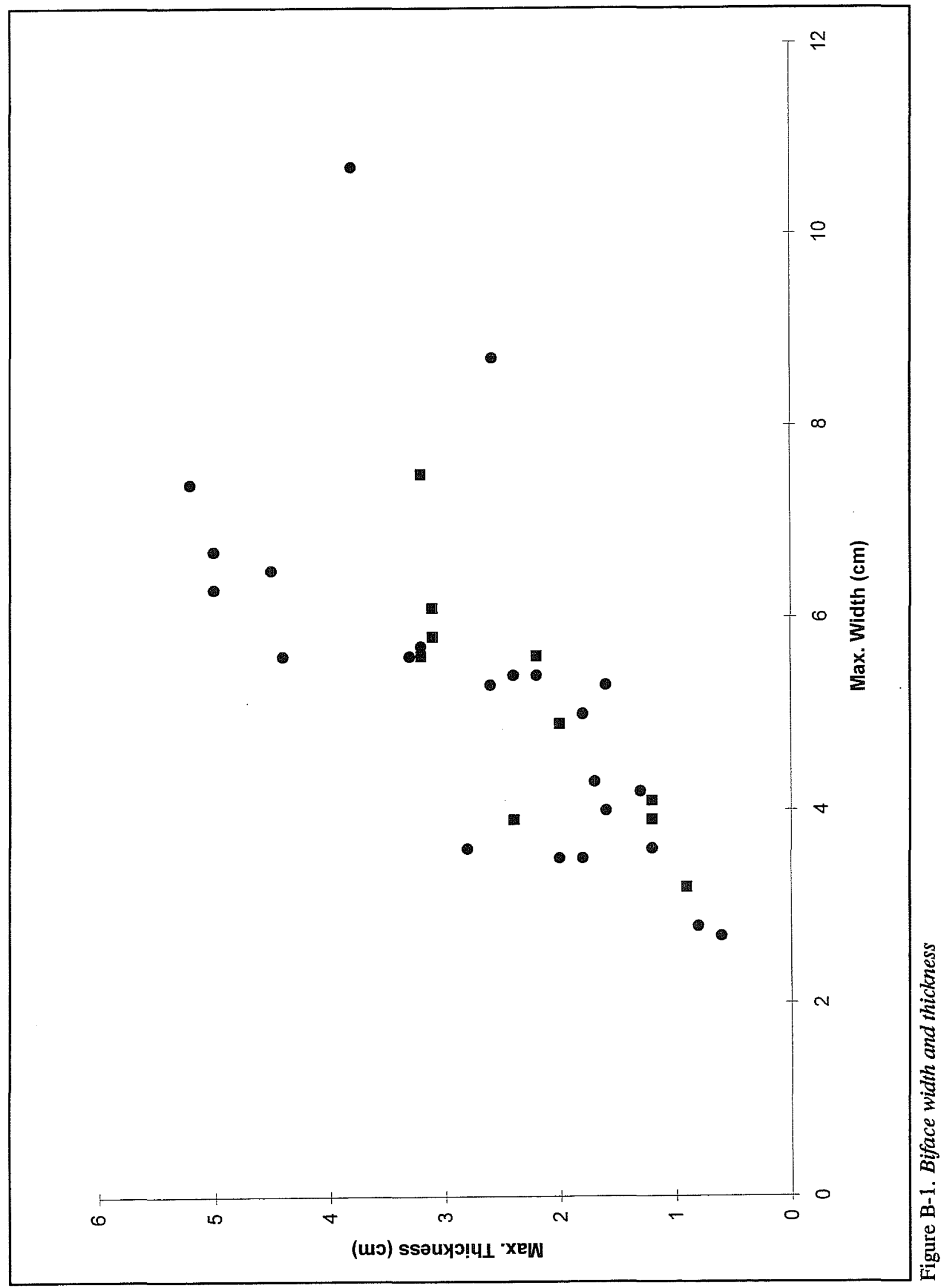




\section{References Cited}

Black, S. L., and A. J. McGraw

1985 The Panther Springs Creek Site: Cultural Change and Continuity with the Upper Salado Creek

Watershed, South-Central, Texas. Archaeological Survey Report, No. 100. Center for Archaeological Research, The University of Texas at San Antonio.

Turner, S. E. and T. R. Hester

1993 A Field Guide to Stone Artifacts of Texas Indians. Gulf, Houston. 

